\title{
Borsa İstanbul ile Türkiye'nin Yüksek Dış Ticaret Hacmine Sahip Ülke Borsalarının Entegrasyonu: Rejim Kaymalı Eşbütünleşme Analizinden Bulgular (Integration of BIST and Stock Exchanges of Countries Having High Foreign Trade Volumes with Turkey: Empirical Evidence from Regime Shift Cointegration Analysis)
}

\section{Yüksel İLTAŞ ${ }^{(D)}$ Fatih GÜZEL (iD) b}

a Kırşehir Ahi Evran Üniversitesi, İ.İ.B.F, İşletme Bölümü, Kırşehir, Türkiye. yiltas@ahievran.edu.tr

b Kırşehir Ahi Evran Üniversitesi, İ.̇̇.B.F, İşletme Bölümü, Kırşehir, Türkiye. fatih.guzel@ahievran.edu.tr

\begin{tabular}{|c|c|}
\hline MAKALE BİLGİsi் & ÖZET \\
\hline $\begin{array}{l}\text { Anahtar Kelimeler: } \\
\text { Borsa İstanbul }\end{array}$ & $\begin{array}{l}\text { Amaç - Bu çalışmanın amacı, yapısal kırılmalar altında Türkiye' nin dış ticaretinde önemli yere sahip } \\
\text { yedi ülke borsa endeksleri arasındaki uzun dönemli eşbütünleşme ilişkisinin varlığını incelemektir. }\end{array}$ \\
\hline $\begin{array}{l}\text { Yüksek Diş Ticaret Hacmi } \\
\text { Eşbütünleşme Analizi }\end{array}$ & $\begin{array}{l}\text { Yöntem - Ocak 2000-Mayıs } 2019 \text { dönemi için Türkiye ile yedi ülke borsa endeksleri arasındaki uzun } \\
\text { dönemli ilişki iki yapısal kırılmaya izin veren Lee ve Strazicich (2003) birim kök testi ve Hatemi-J } \\
\text { (2008) eşbütünleşme testi ile incelenmiştir. }\end{array}$ \\
\hline $\begin{array}{l}\text { Gönderilme Tarihi } 18 \text { Eylül } \\
2019 \\
\text { Revizyon Tarihi } 28 \text { Kasım } 2019 \\
\text { Kabul Tarihi } 10 \text { Aralık } 2019\end{array}$ & $\begin{array}{l}\text { Bulgular - Dickey-Fuller (ADF;1981), Phillips-Perron (PP;1988) ile Lee ve Strazicich (2003) birim kök } \\
\text { testi sonuçlarına göre serilerin bütünleşme dereceleri I(1) olarak belirlenmiştir. Hatemi-J (2008) } \\
\text { yapısal kırılmalı eşbütünleşme testi BIST100 ile DAX 30, FTSE 100, IMOEX, CAC } 40 \text { ve S\&P 500 } \\
\text { arasında uzun dönemli bir ilişkinin olduğunu, fakat FTMIB ve IBEX ile uzun dönemli bir ilişki } \\
\text { bulunmadığını göstermektedir. }\end{array}$ \\
\hline $\begin{array}{l}\text { Makale Kategorisi: } \\
\text { Araştırma Makalesi }\end{array}$ & $\begin{array}{l}\text { Tartışma - Eşbütünleşme testi sonuçlarının BIST } 100 \text { ile incelenen borsaların (DAX 30, FTSE 100, } \\
\text { IMOEX, CAC } 40 \text { ve S\&P 500) beşi arasında farklı kırılma tarihleri için farklı ilişkilerin olduğu işaret } \\
\text { etmesi, incelenen dönemde meydana gelen yapısal değişimlerin borsa endeksleri arasındaki ilişki } \\
\text { üzerinde etkili olduğunu göstermektedir. Ayrıca yatırımcılar uzun dönemli ilişki tespit edilemeyen } \\
\text { borsa endekslerine yatırım yapıp, portföy çeşitlendirmesi yaparak risklerini azaltabileceklerdir. }\end{array}$ \\
\hline
\end{tabular}

\begin{tabular}{|c|c|}
\hline ARTICLE INFO & ABSTRACT \\
\hline $\begin{array}{l}\text { Keywords: } \\
\text { BIST } \\
\text { High Foreign Trade Volumes } \\
\text { Cointegraiton Analysis }\end{array}$ & $\begin{array}{l}\text { Purpose - The aim of this study is to examine the existence of a cointegration relationship under } \\
\text { structural breaks, between Turkey and stock indices of seven countries that has a key impact over } \\
\text { Turkey's foreign trade. } \\
\text { Design/methodology/approach - Long term relationship between Turkey and the seven countries } \\
\text { stock indexes for January 2000-May } 2019 \text { period is examined by Lee and Strazicich (2003) two } \\
\text { structural breaks unit root test and Hatami-J (2008) cointegration test. } \\
\text { Findings - According to Dickey-Fuller (ADF; 1981), Phillips-Perron (PP; 1988) and Lee and } \\
\text { Strazicich (2003) unit root test results, the degree of integration of the series was determined as I(1). } \\
\text { Hatemi-J (2008) cointegration test with two structural breaks shows that there is a long-term } \\
\text { relationship between BIST100 and DAX 30, FTSE 100, IMOEX, CAC } 40 \text { and S\&P 500, while there is } \\
\text { no long-term relationship wtih FTMIB and IBEX 35. } \\
\text { Discussion - The results of the cointegration test indicate that for different break periods there are } \\
\text { different relationships between BIST } 100 \text { and five of the seven stock exchanges (DAX 30, FTSE } 100 \text {, } \\
\text { IMOEX, CAC } 40 \text { and S\&P 500), this denotes that the structural changes occurring in the analysis } \\
\text { period have an effect on the relationship between stock market indices. In addition, investors will } \\
\text { be able to reduce their risks by investing in stock exchange indices which has not long term } \\
\text { relationship (cointegration), in other words non-cointegrated instruments are suitable for portfolio } \\
\text { diversification. }\end{array}$ \\
\hline
\end{tabular}

\section{Önerilen Atıf/Suggested Citation}

İltaş, Y., Güzel, F. (2019) Borsa İstanbul ile Türkiye'nin Yüksek Dış Ticaret Hacmine Sahip Ülke Borsalarının Entegrasyonu: Rejim Kaymalı Eşbütünleşme Analizinden Bulgular, İşletme Araştırmaları Dergisi, 11 (4), 3051-3062. 


\section{Giriş}

Özellikle 1970'li yılları takip eden süreçte ülkeler, küreselleşme ve finansal liberalizasyon akımları çerçevesinde diğer ülkeler ile ticari faaliyetlerini geliştirme imkânı bulmuştur. Ülkeler arasında gelişen ticaret ise, ülke ekonomileri arasındaki etkileşim ve bağımlılı̆̆ın artması sonucunu doğurmuştur. Ülkelerin diğer ülkelerle mevcut veya potansiyel ilişkileri ise, risk dağıtımı ve portföy çeşitlendirmesi açısından yatırımcıları, ticaret ve kalkınma açısından politika yapıcıları yakından ilgilendirmektedir. Ayrıca, toplumun farklı kesimleri de doğrudan veya dolaylı olarak bu ilişkilerden etkilenmektedir. Dolayısıyla, piyasaların birbirleriyle olan etkileşimlerin tespiti hem teorik hem de uygulama açısından önem taşımaktadır.

24 Ocak 1980 Kararları olarak bilinen istikrar paketi, Türkiye'nin liberal ekonomi sistemine geçişi aşamasında kilometre taşı olarak kabul edilmektedir. 24 Ocak 1980 Kararları ile genel anlamda Türkiye'nin küresel standartlarda bir piyasa yapısına sahip olması ve küresel ekonomiye entegrasyonu amaçlanmıştır. Serbest döviz piyasası, menkul kıymetler borsası ve türev ürünler borsası gibi oluşturulan yapılar bu düşüncenin ürünleridir. İkili ticaret anlaşmaları, gümrük birliği anlaşması ve güçlü sermaye piyasasının da yardımıyla Türkiye son dönemde küresel ekonomiden aldığı payı artırma gayreti içerisindedir. Türkiye hem ticaret yelpazesindeki ülke sayısını artırmaya çalışmakta hem de ticaret yaptığı mevcut ülkeler ile ilişkilerini derinleştirmektedir. Türkiye geliştirdiği ticari ilişkiler neticesinde küresel piyasalara entegrasyon düzeyini artırırken, aynı zamanda dış dünyadaki faktörlere karşı daha hassas bir pozisyona girmektedir.

Finansal piyasalar arasındaki etkileşimin analizi adına çeşitli parametreler kullanılmaktadır. Bununla birlikte, borsa endeksleri ekonominin göstergesi olarak kabul edilmekte ve piyasalar arası etkileşimin araştırılmasında sıklıkla tercih edilmektedir. Yüksek kotasyon oranı ve gelişmiş sermaye piyasalarına sahip ülkelerin borsa endeksleri daha etkin birer göstergedir. Bu noktadan hareketle, çalışmada Türkiye ile gelişen ve gelişmiş ülkeler arasındaki etkileşimler incelenmektedir. Gösterge parametresi olarak borsa endeksleri kullanılmıştır. İncelenen ülkeler ise Türkiye'nin yüksek ticaret hacmine sahip olduğu ülkeler arasından seçilmiştir ve genel itibarıla etkin birer borsaya sahiptirler. Finans ve ekonomi literatüründe değişkenler arasındaki eşbütünleşme ilişkisini incelemede Engle ve Granger (1987), Johansen (1988) ve Johansen ve Juselius (1990) tarafından geliştirilen testler yaygın biçimde kullanılmaktadır. Her üç test de uzun dönem parametrelerin zaman içinde değişmediği gibi güçlü bir varsayım yapılmaktadır. Öte yandan bir ekonomide savaşlar, doğal felaketler, ekonomi politikalarındaki değişmeler ve ekonomik krizler gibi önemli gelişmeler nedeniyle uzun dönem parametreler zaman içinde değişebilir. Bu yüzden, yukarıda belirtilen testleri kullanan araştırmacılar yanlı ve sapmalı sonuçlar elde edebilirler. Bu çalışmada bu olası durumdan kaçınmak için Hatemi-J (2008) tarafından geliştirilen ve iki yapısal kırılmaya/rejim kaymasına izin veren eşbütünleşme testi kullanılmıştır. $\mathrm{Bu}$ açıdan bakıldığında, bu çalışma ülke borsaları arasındaki eşbütünleşme ilişkisini incelerken rejim kaymasına, diğer bir deyişle uzun dönem katsayıların zaman içinde değişmesine, izin veren çalışmadır. Bu bağlamda, çalışmanın literatüre katkı sağlayacağı düşünülmektedir. Çalışmadan elde edilen bulgular, rejim kayması tarihlerinin katsayılar üzerinde ciddi etkiler yarattığını göstermekte ve bu nedenle seçilen yöntemin yerinde ve uygun olduğunu doğrulamaktadır. Çalışmanın müteakip bölümleri sırasıyla, literatür özeti, veri seti ve ekonometrik metodoloji, ampirik bulgular ve sonuçlardan oluşmaktadır.

\section{Literatür}

Literatürde borsa endeksleri arasındaki etkileşimin analizi belirli bir ekonomik organizasyon (BRICS, G-8 vb.), coğrafi grup (Asya, MENA vb.) veya seçilen ülkeler çerçevesinde yapılmaktadır. Bu nedenle literatür özeti aynı veya yakın örnekleme sahip olan çalışmaların gruplanması şeklinde olacaktır. Aynı ülke ekonomik ve coğrafi açıdan farklı topluluklarda yer alabiliyor olsa da bu gruplandırma anlatımın sadeleşmesi açısından önemlidir.

Türkiye'nin $A B$ ve $A B$ üyeleri arasından seçilen ülkeler ile etkileşimine yönelik geniş bir literatür bulunmaktadır ve bazı örneklerine burada yer verilmiştir. Mandacı ve Taşkın (2005) tarafından 2000-2004 dönemi için Türkiye ile 17 Avrupa borsası ${ }^{1}$, işlem hacmi ve piyasa değeri gibi çeşitli kriterlere göre kıyaslanmış ve borsalar arasındaki korelasyon incelenmiştir. IMKB'nin Avrupa borsalarına göre daha yüksek risk ve getiri oranına sahip olduğu gözlenmiştir. Ayrıca, Avrupa borsaları ile İMKB arasındaki korelasyonun oldukça

1 Almanya, Avusturya, Danimarka, Belçika, Fransa, Hollanda, Portekiz, Finlandiya, İngiltere, İrlanda, İspanya, İsveç, İtalya, Macaristan, Norveç, Polonya ve Yunanistan. 


\section{Y. İltaş - F. Güzel 11/4 (2019) 3051-3062}

düşük çıktığı gözlenmiş ve İMKB'nin Avrupa borsalarına alternatif bir yatırım aracı olabileceği sonucuna varılmıştır. Ceylan (2006) 2000-2005 dönemini kapsayan çalışmasında, AB (MSCI EU), ABD (S\&P 500), Bulgaristan, Hırvatistan, Romanya ile Türkiye borsalarının etkileşimini incelemiştir. Belirtilen endeksler arasında düşük korelasyon tespit edilmiş ve eşbütünleşme ilişkisine rastlanmamıştır. Nedensellik ilişkisinin Türkiye borsasından Bulgaristan borsasına doğru olduğu tespit edilmiş, diğer endeksler arasında ise nedensellik ilişkisi bulunmadığı raporlanmıştır. Boztosun ve Çelik (2011) 2002-2009 dönemi için, İMKB ile Avrupa borsaları ${ }^{2}$ arasındaki etkileşimi araştırmıştır. Önceki yıllarda yapılan çalışmaların aksine, Türkiye ile Avrupa borsaları arasında -Hollanda hariç olmak üzere- yüksek korelasyon tespit edilmiştir. Bununla birlikte, Türkiye ile Almanya, Belçika, Hollanda, İngiltere ve Norveç borsalarının eşbütünleşik, diğer ülke borsalarının ise, eşbütünleşik olmadığ 1 ifade edilmiştir.

$\mathrm{AB}$ dışındaki diğer ekonomik organizasyonların üye ülkeleri ile Türkiye borsaları arasındaki etkileşimlere yönelik çalışmaların da literatürde yer aldığı görülmektedir. Bozoklu ve Saydam (2010), 2005-2010 dönemi için Türkiye ve BRIC $^{3}$ ülkeleri arasında eşbütünleşme ilişkisi tespit etmiştir. Özşahin (2017) ise, Türkiye ile BRICS4 ülkeleri arasındaki etkileşimleri 2000-2016 dönemi için incelemiştir. Elde edilen bulgulara göre Rusya, Hindistan, Çin ve Güney Afrika ile Türkiye borsaları uzun dönemde birlikte hareket etmektedir ve bu borsalar arasında portföy çeşitlendirmesi yapmak mümkün değildir. Polat ve Gemici (2017) ise, Türkiye ile BRICS ülke borsaları arasındaki eşbütünleşme ilişkisini Ocak 2003-Haziran 2017 dönemi aylık veriler aracılığıyla incelemiştir. Elde edilen bulgulara göre, Türkiye ile Hindistan ve Brezilya borsaları arasında hem uzun hem de kısa dönemde, Türkiye ile Rusya arasında sadece kısa dönemde eşbütünleşme ilişkisi bulunmaktadır. Yağlı (2016), 2001-2016 yıllarını kapsayan çalışmasında Amerika Birleşik Devletleri ile BRICS ülkeleri ve Türkiye hisse senedi piyasaları arasındaki eşbütünleşme ilişkisini Johansen Eşbütünleşme testi ile incelemiştir. Araştırmadan elde edilen bulgulara göre ABD ile BRICS ülkelerinin hisse senedi piyasaları arasında uzun dönemli ilişkiye rastlanmamıştır. Kocabıyık ve Kalaycı (2014), 2003-2012 dönemi için Türkiye ile G-85 ülke borsalarının etkileşimini incelemiştir. İlgili dönemde Türkiye ve G-8 ülkeleri arasında, kısa ve uzun dönem ilişkiye rastlanmadığı bildirilmiştir. Sevüktekin ve Nargeleçekenler (2008), 1986-2007 dönemi için Amerikan Borsa Endeksleri (Dow Jones, Nasdaq ve S\&P 500) ile İMKB arasındaki etkileşimi incelemişlerdir. İlgili borsalar arasında uzun dönemli ilişki tespit edilmiştir. Uzun dönemli nedensellik analizlerinde çift yönlü nedensellik, kısa dönem nedensellik analizlerinde ise, Amerikan borsalarından İMKB'ye doğru tek yönlü nedensellik ilişkisinin var olduğu sonucuna ulaşılmıştır.

Literatürde yer alan başka bir çalışma alanı ise Türkiye ile gelişen ve gelişmiş ülkeler arasındaki etkileşimdir. Çıtak ve Gözbaşı (2007), İMKB ile ABD, Almanya, Hindistan, İngiltere, Japonya ve Malezya borsaları arasındaki ilişkiyi 1986-2006 dönemi için araştırmışlardır. Çalışmada İMKB ile ABD, Almanya, Hindistan ve İngiltere borsaları arasında uzun dönemli ilişki saptanmıştır. Korkmaz vd. (2009) ise, 1995-2007 dönemi için İMKB ile çok sayıda gelişmiş ${ }^{6}$ ve gelişmekte ${ }^{7}$ olan ülke borsasının etkileşimini incelemişlerdir. Farklı eşbütünleşme testlerinin uygulandığı çalışmada testlerin ortak sonuçlarına göre; İMKB ile ABD, Avustralya, Belçika, İngiltere, İrlanda, İspanya, Portekiz ve Macaristan borsalarının eşbütünleşik olmadığı vurgulanmıştır. Bu borsaların çeşitlendirme adına portföy oluşturmada kullanılabileceği belirtilmiştir. Vuran (2010) 2006-2009 dönemi için, İMKB ile çeşitli pay senedi endekslerinin ${ }^{8}$ etkileşimini incelemiştir. Yapılan analizler sonucunda, İMKB ile Almanya, Arjantin, Brezilya, İngiltere ve Meksika borsalarının eşbütünleşik olduğu saptanmıştır. Kaya (2016) Ocak 2010-Aralık 2011 döneminde haftalık veriler bazında BİST 100 endeksi ile Merval (Arjantin), DJIA, Bombay (Hindistan), Shanghai (Çin) ve CAC (Fransa) endeksleri arasındaki eşbütünleşme ilişkisini araştırmıştır. Elde edilen bulgulara göre, ilgili dönemde BIST 100 ile ABD ve Arjantin borsaları arasında eşbütünleşme ilişkisinin bulunduğu ifade edilmiştir. Öztürk (2018) ise, BİST 30 endeksi ile MSCI gelişen

2 Almanya, Avusturya, Belçika, Fransa, Hollanda, İngiltere, İspanya, İsveç, İsviçre ve Norveç.

3 Brezilya, Rusya, Hindistan ve Çin'in baş harflerinin kısaltmasıdır ve ilgili ülke ekonomilerini ifade etmek için kullanılmaktadir.

${ }^{4}$ Brezilya, Rusya, Hindistan, Çin, Güney Afrika

5 G-8; Japonya, Rusya, İtalya, Almanya, Fransa, İngiltere, ABD ve Kanada ülkelerinden oluşmaktadır.

6 Almanya, ABD, Avusturya, Avustralya, Belçika, Danimarka, Finlandiya, Fransa, Hollanda, Hong Kong, İngiltere, İrlanda, İspanya, İsveç, İtalya, Japonya, Kanada, Kanada, Norveç, Portekiz, Singapur, Yeni Zelanda ve Yunanistan.

7 Arjantin, Brezilya, Çek Cumhuriyeti, Çin, Endonezya, Filipinler, Güney Kore, Hindistan, İsrail, Kolombiya, Macaristan, Malezya, Meksika, Mısır, Pakistan, Peru, Polonya, Rusya, Sri Lanka, Şili, Tayland, Tayvan ve Türkiye.

8 ABD, Almanya, Arjantin, Brezilya, Fransa, İngiltere, Japonya ve Meksika 


\section{Y. İltaş - F. Güzel 11/4 (2019) 3051-3062}

piyasalar (MSCI-EF9) endeksi arasındaki eşbütünleşme ilişkisini Ocak 2003-Temmuz 2017 dönemi aylık verileri aracılı̆̆ıyla incelemiştir. Veri seti 2008 finansal krizi öncesi ve sonrası olarak iki dönem olarak ayrılmıştır. Elde edilen bulgular, kriz öncesinde BİST 30 ile MSCI-EF endeksi arasında eşbütünleşme ilişkisinin bulunmadığını ancak kriz sonrası ve tüm dönem dikkate alındığında ilgili endeksler arasında eşbütünleşme ilişkisinin mevcut olduğuna işaret etmektedir.

Türkiye ile yüksek ticaret hacmine sahip olduğu ülke borsaları arasındaki etkileşim literatürde başka bir araştırma alanını oluşturmaktadır. Korkmaz vd. (2008), 1995-2007 dönemi için İMKB ile AB üyesi 18 ülke ${ }^{10}$ ve Türkiye'nin yoğun ticaret hacmine sahip olduğu 10 ülke ${ }^{11}$ borsası arasındaki etkileşimi incelemişlerdir. Yapılan analiz sonuçlarına göre; Türkiye ile yoğun dış ticaret hacmine sahip olduğu ülke borsaları arasında korelasyon oranı oldukça düşüktür. Ayrıca, İMKB ile AB üyesi ülkelerinden Belçika, İngiltere, İrlanda, İspanya, Macaristan ve Portekiz ve yoğun ticaret hacminin bulunduğu $A B D$, İngiltere ve İspanya pay senedi piyasaları arasında eşbütünleşme ilişkisi tespit edilememiştir. İMKB ile diğer ülke piyasaları arasında eşbütünleşme ilişkisi bulunduğu belirtilmiştir. Yılancı ve Öztürk (2010), 1995-2009 dönemi için İMKB ile Türkiye'nin beş ticaret ortağı ülke (ABD, Almanya, Hollanda, İspanya ve İngiltere) borsaları arasındaki ilişkiyi incelemişlerdir. Elde edilen bulgulara göre; IMKB ile Hollanda, İngiltere ve ABD arasında bir eşbütünleşme ilişkisine rastlanmamıştır. İMKB yatırımcıları için ilgili piyasaların portföy çeşitlendirmesinde ikame olarak kullanılabileceği belirtilmiştir.

\section{Veri Seti ve Ekonometrik Metodoloji}

Araştırmaya ait veri seti ve ekonometrik metodolojiye ait bilgiler iki ayrı alt başlıkta sunulmaktadır.

\subsection{Veri Seti}

Çalışmanın veri seti Ocak 2000 - Mayıs 2019 dönemini kapsayan aylık borsa endeksi kapanış değerlerinden oluşmaktadır. Türkiye ile dış ticaretinde önemli yere sahip yedi ülke borsası arasındaki ilişkinin niteliği tespit edilmeye çalışılmaktadır. Aşağıda, Tablo 1'de çalışmaya konu olan ülkelerin menkul kıymet borsalarına ilişkin bilgiler sunulmuştur.

Tablo 1: Çalışmada İncelenen Ülkeler ve Borsa Endeksleri

\begin{tabular}{|l|l|c|c|}
\hline \multicolumn{1}{|c|}{ Ülke } & \multicolumn{1}{c|}{ Borsa İsmi } & Borsa Endeksi & Dönem \\
\hline Türkiye & Borsa İstanbul & BİST100 & 2000:01-2019:05 \\
\hline Almanya & Frankfurt Borsası & DAX 30 & 2000:01-2019:05 \\
\hline Rusya & Moskova Borsası & IMOEX & 2000:01-2019:05 \\
\hline İtalya & FTSE İtalya Borsası & FTMIB & 2000:01-2019:05 \\
\hline ABD & Şikago Borsa Kurulu & S\&P 500 & 2000:01-2019:05 \\
\hline İngiltere & Londra Menkul Kiymetler Borsas1 & FTSE 100 & 2000:01-2019:05 \\
\hline Fransa & Euronext Paris Borsası & CAC 40 & 2000:01-2019:05 \\
\hline İspanya & Madrid Borsas1 & IBEX 35 & 2000:01-2019:05 \\
\hline
\end{tabular}

Çalışmaya konu olan ülkeler için sırasıyla ABD (S\&P 500), Almanya (DAX 30), Fransa (CAC 40), İngiltere (FTSE 100), İspanya (IBEX 35), İtalya (FTMIB), Rusya (IMOEX) ve Türkiye (BİST 100) olmak üzere, ülke borsalarının temel piyasa endeksleri kullanılmıştır. Çalışmaya dahil edilen verilerin logaritması alınmıştır. Veriler ilgili borsaların resmi internet sitesi ve Yahoo Finans adreslerinden sağlanmıştır. Ocak 2000 - Mayıs 2019 dönemi için 233 gözlem değeri veri setini oluşturmaktadır.

Aşağıda, Tablo 2'de çalışmaya konu olan değişkenler ve Türkiye dış ticaretinde sahip oldukları paylara yer verilmiştir:

\footnotetext{
${ }^{9}$ MSCI gelişen piyasalar endeksi içerisinde Birleşik Arap Emirlikleri, Brezilya, Çek Cumhuriyeti, Çin, Endonezya, Filipinler, Güney Afrika, Hindistan, Katar, Kolombiya, Kore, Macaristan, Malezya, Meksika, Misır, Pakistan, Peru, Polonya, Rusya, Şili, Tayvan, Tayland, Türkiye ve Yunanistan yer almaktadır.

10 Almanya, Avusturya, Belçika, Çek Cumhuriyeti, Danimarka, Finlandiya, Fransa, Hollanda, İngiltere, İrlanda, İspanya, İsveç, İtalya, Macaristan, Norveç, Polonya, Portekiz ve Yunanistan.

11Almanya, ABD, Çin, Fransa, Hollanda, İngiltere, İspanya, Güney Kore, İtalya ve Rusya.
} 
Y. İltaş - F. Güzel 11/4 (2019) 3051-3062

Tablo 2: Çalışmada Yer Alan Ülkelerin Türkiye Dış Ticaret Payları (Milyon \$)

\begin{tabular}{|c|l|r|c|r|c|c|c|}
\hline Sira & \multicolumn{1}{|c|}{ Ülke } & \multicolumn{1}{c|}{ İthalat } & $\begin{array}{c}\text { Ülkenin } \\
\text { Yüzdesi }\end{array}$ & \multicolumn{1}{c|}{ İhracat } & $\begin{array}{c}\text { Ülkenin } \\
\text { Yüzdesi }\end{array}$ & $\begin{array}{c}\text { İthalat + } \\
\text { İhracat }\end{array}$ & $\begin{array}{c}\text { Ülkenin } \\
\text { Yüzdesi }\end{array}$ \\
\hline 1 & Almanya & $207.120,16$ & $9,59 \%$ & $135.868,77$ & $9,54 \%$ & $342.988,93$ & $9,57 \%$ \\
\hline 2 & Rusya & $219.049,55$ & $10,14 \%$ & $44.853,66$ & $3,15 \%$ & $263.903,21$ & $7,36 \%$ \\
\hline 3 & İtalya & $111.786,00$ & $5,17 \%$ & $72.980,09$ & $5,12 \%$ & $184.766,09$ & $5,15 \%$ \\
\hline 4 & ABD & $122.721,56$ & $5,68 \%$ & $59.151,97$ & $4,15 \%$ & $181.873,53$ & $5,07 \%$ \\
\hline 5 & İngiltere & $56.693,76$ & $2,62 \%$ & $91.659,54$ & $6,44 \%$ & $148.353,30$ & $4,14 \%$ \\
\hline 6 & Fransa & $79.736,58$ & $3,69 \%$ & $63.850,03$ & $4,48 \%$ & $143.586,61$ & $4,01 \%$ \\
\hline 7 & İspanya & $56.463,81$ & $2,61 \%$ & $46.814,64$ & $3,29 \%$ & $103.278,45$ & $2,88 \%$ \\
\hline & $\begin{array}{l}\text { Genel } \\
\text { Toplam }\end{array}$ & $2.160 .397,28$ & & $1.424 .089,24$ & & $3.584 .486,52$ & $38,18 \%$ \\
\hline
\end{tabular}

Kaynak: www.tuik.gov.tr.

Seçilen ülkelerin Türkiye dış ticaret hacminin $\% 40$ 'ını temsil ettiği gözlenmektedir. Türkiye dış ticaret yelpazesi oldukça geniş bir ülkedir ve buradaki ülkelerle sınırlı değildir. Ancak, analizlerin yönetimi ve veri temini gibi kısıtlar nedeniyle değişken sayısı kısıtlanmıştır. Bununla birlikte, ilgili ülkeler yıllar itibarıyla sıralamaları değişse bile Türkiye dış ticaretinde ilk sıralarda yer almaktadır.

\subsection{Ekonometrik Metodoloji}

Çalışmada serilerin durağanlık düzeyleri literatürde sıklıkla kullanılan Artırılmış Dickey-Fuller (ADF; 19791981) ve Phillips-Perron (PP;1988) standart birim kök testlerinin yanı sıra iki içsel kırılmaya izin veren Lee ve Strazicich (2003) birim kök testi ile sınanmıştır. Serilerin bütünleşme derecelerinin (I(1)) belirlenmesinden sonra, seriler arasında olası uzun dönemli eşbütünleşme ilişkilerinin varlığı yapısal değişimleri dikkate alan Hatemi-J (HJ) (2008) eşbütünleşme testi ile analiz edilmiştir. Uzun döneme ait katsayıların tahmin edilmesinde HJ'nin yapısal kırılmaları dikkate alarak uzun dönem katsayılarını tahmininde kullandığı en küçük kareler (EKK) yöntemi kullanılmıştır.

\subsubsection{Lee ve Strazicich (2003) Birim Kök Testi}

Zivot ve Andrews (1992) ve Lumsdaine ve Papell (1997) birim kök testlerinin temel hipotezi (Ho) yapisal kırılmasız serinin birim köklü olduğu, alternatif hipotez $\left(\mathrm{H}_{1}\right)$ ise serinin yapısal kırılmalarla birlikte durağan olduğu yönündedir. Lee ve Strazicich $(2003,2004)$ bu testlerde ileri sürülen temel hipotezin alternatifinin "yapısal kırılmalı durağan" olmaması gerektiğini savunmuşlardır. Çünkü temel hipotezde yapısal kırılma olmadığı varsayılıyorsa alternatif hipotezde de yapısal kırılmaların var olması gerekir, bu ise incelenen seride yapısal kırılmalı birim kökün var olabileceğini gösterir (Yılancı, 2009: 329). Lee ve Strazicich (2003, 2004), Schmidt ve Phillips (1992) Lagrange Çarpanları (LM) birim kök testine dayanan, temel ve alternatif hipotezde kırılmaya izin veren içsel iki kırılmalı Lagrange Çarpanları birim kök testini literatüre kazandırmışlardır.

Lee ve Strazicich birim kök testi için Perron (1989)'daki üç yapısal kırılmalı (Model A, B ve C) modeli dikkate almış ve aşağıdaki regresyon denklemine göre veri üretmişlerdir (Lee ve Strazicich, 2003: 1082-1083).

$$
y_{t}=\delta^{\prime} Z_{t}+e_{t} \quad e_{t}=\beta e_{t-1}+\varepsilon_{t}
$$

Eşitlikte yer alan $Z_{t}$, veri üretme sürecinde dışsal değişkenleri içeren vektörü ifade eder ve aşağıdaki gibi tanımlanmaktadır.

$$
Z_{t}=\left[1, t, D_{1 t}, D_{2 t}\right]^{\prime} \quad i=1,2 \text { için }
$$

Eşitlikte yer alan kukla (gölge) değişken aşağıdaki gibi tanımlanmaktadır.

$$
D_{i t}=\left\{\begin{array}{l}
1, t \mathrm{t} \geq T_{B i}+1 \text { iken } \\
0, \text { diğger durumlarda }
\end{array}\right\}
$$

Burada $T_{B i}$ kırılma zamanını göstermektedir. 
Düzeyde ve eğimde iki kırılmaya izin veren $Z_{t}$ değişkeni aşağıdaki gibi elde edilmektedir.

$$
Z_{t}=\left[1, t, D_{1 t}, D_{2 t}, D T_{1 t}, D T_{2 t}\right]^{\prime}, i=1,2 \text { için }
$$

Buradaki kukla değişken ise şöyle elde edilmektedir.

$$
D T_{i t}=\left\{\begin{array}{l}
t-T_{B i}, t \geq T_{B i}+1 \text { iken } \\
0, \text { diğer durumlarda }
\end{array}\right\}
$$

Lee ve Strazicich kırılmalı birim kök testinde veri yaratma süreci temel hipotez altında kırılmaları içerirken $(\beta=1)$, alternatif hipotez $(\beta<1)$, şeklindedir. Lee ve Strazicich kırılmalı birim kök test istatistiği (LM) aşağıdaki regresyondan elde edilir.

$$
\Delta y_{t}=\delta^{\prime} \Delta Z_{t}+\phi \tilde{S}_{t-1}+u_{t}
$$

Eşitlikte, $\tilde{S}=y_{t}-\tilde{\Psi}_{x}-Z_{t} \tilde{\delta}^{\wedge}, \quad \mathrm{t}=2, \ldots, \mathrm{T}$ şeklindedir. $\tilde{\delta} ; \Delta y_{t}{ }^{\prime}$ nin $\Delta Z_{t}{ }^{\prime}$ ye göre regresyonundan elde edilen katsayılardır. $\tilde{\Psi}_{x}, y_{1}-Z_{1} \tilde{\delta}$ ile elde edilir. LM istatistiği birim kök temel hipotezi $\varphi=0 \mathrm{t}$ istatistiği ile sınanır (Yilanc1, 2009: 330).

\subsubsection{Hatemi-J Eşbütünleşme Testi}

Ekonometrik çalışmalarda serilerin durağanlık düzeyleri belirlendikten sonra eşbütünleşme testleri aracılığıyla seriler arasındaki uzun dönemli eşbütünleşme ilişkisinin varlığı yani değişkenlerin uzun dönemde birlikte hareket edip etmediği araştırılmaktadır. Gregory ve Hansen (1996) tarafından literatüre kazandırılan eşbütünleşme testinde yapısal kırılma tarihi içsel olarak belirlenmekte ve bir yapısal kırılmaya izin verilmektedir. Hatemi-J (2008) tarafından geliştirilen eşbütünleşme testi, bir içsel kırılmaya izin veren Gregory ve Hansen (1996) eşbütünleşme testinin iki yapısal kırılmaya izin verecek şekilde genişletilmiş şeklidir. Hatemi-J (2008) eşbütünleşme testinde analiz için ilk olarak aşağıdaki eşitlik dikkate alınmaktadır (Hatemi-J, 2008: 498-499).

$$
y_{t}=\alpha+\beta^{\prime} x_{t}+u_{t}, \quad t=1,2, \ldots, n \text {. }
$$

Hatemi-J çalışmasında (3) numaralı eşitliği hem sabitte hem de eğimde iki yapısal kırılmanın etkisi dikkate alarak aşağıdaki gibi genişletmiştir.

$$
y_{t}=\alpha_{0}+\alpha_{1} D_{1 t}+\alpha_{2} D_{2 t}+\beta_{0}^{\prime} x_{t}+\beta_{1}^{\prime} D_{1 t} x_{t}+\beta_{2}^{\prime} D_{2 t} x_{t}+u_{t}
$$

(4) numaralı eşitlikte $D_{1 t}$ ve $D_{2 t}$ yapısal kırılmaların (değişimlerin) etkilerini modele dahil eden kukla değişkenler olup aşağıdaki gibi tanımlanmaktadır:

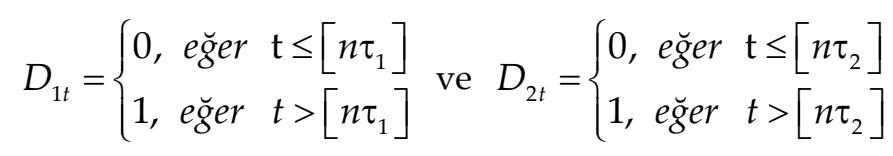

(4) numaralı eşitlikte $\alpha_{0}$ yapısal değişimlerden önceki sabit terimi gösterirken, $\alpha_{1}$ ve $\alpha_{2}$ birinci ve ikinci yapısal kırılma nedeniyle sabit terimde meydana gelen değişimi göstermektedir. Yapısal değişimlerden önce eğim parametresini $\beta_{0}$ gösterirken, birinci ve ikinci yapısal değişimin eğimde meydana getirdiği etkiyi sırasıyla $\beta_{1}$ ve $\beta_{2}$ parametreleri göstermektedir (Yllancı ve Öztürk, 2009: 267).

Hatemi-J (2008) eşbütünleşme testinde değişkenler arasında eşbütünleşme ilişkisi yoktur temel hipotezi, değişkenler arasında iki yapısal kırılmayla birlikte eşbütünleşme ilişkisi vardır alternatif hipotezine karşı sınanmasında $A D F^{*}, Z_{\alpha}$ ve $Z_{t}$ test istatistikleri kullanılarak üç model tahmin edilmektedir. Bu modellerden ilki Model $2(C)$ seviyede kayma, ikinci model olan Model $3(\mathrm{C} / \mathrm{T})$ seviyede ve eğimde kayma ve üçüncüsü Model 4 (C/S) rejim değişimi (kayması) olarak ifade edilmekte ve ilgili test istatistikleri aşağıdaki gibi elde edilmektedir (Hatemi-J, 2008: 500): 


$$
\begin{aligned}
A D F^{*} & =\inf _{\left(\tau_{1}, \tau_{2}\right) \in T} A D F\left(\tau_{1}, \tau_{2}\right) \\
Z_{t}^{*} & =\inf _{\left(\tau_{1}, \tau_{2}\right) \in T} Z_{t}\left(\tau_{1}, \tau_{2}\right) \\
Z_{\alpha}^{*} & =\inf _{\left(\tau_{1}, \tau_{2}\right) \in T} Z_{\alpha}\left(\tau_{1}, \tau_{2}\right)
\end{aligned}
$$

Burada $T=(0,15 n, 0,85 n)$ ve yukarıda verilen her üç istatistik standart olmayan dağılıma sahiptir. Bu üç testin tüm $\tau_{1}$ ve $\tau_{2}$ değerleri için hesaplanan test istatistiklerinin en küçük olanı kullanılır $\left(\tau_{1} \in T_{1}=(0.15,0.70)\right.$ ve $\left.\tau_{2} \in T_{2}=\left(0.15+\tau_{1}, 0.70\right)\right)$. Kritik değerler Hatemi-J (2008) Tablo 1'de raporlanmıştır.

\section{Ampirik Bulgular}

\subsection{Birim Kök Testi Sonuçları}

Çalışmanın bu kısmında analize dahil edilen serilerin birim kök içerip içermediğine yönelik test sonuçları verilecektir. Öncelikle literatürde en çok tercih edilen Artırılmış Dickey-Fuller (ADF;1981) ve Phillips-Perron (PP;1988) standart birim kök testleri uygulanarak serilerin durağanlıkları incelenmiş ve sonuçları Tablo 3'te sunulmaktadır. Modele dahil edilen tüm değişkenlerin seviye ve birinci fark değerlerine uygulanan yapısal kırılmalı Lee ve Strazicich (2003) birim kök test sonuçları Tablo 4'te rapor edilmektedir.

Tablo 3: ADF ve PP Birim Kök Test Sonuçları

\begin{tabular}{ccccc}
\hline \multirow{2}{*}{ Değişken } & \multicolumn{2}{c}{ ADF Test İstatistiği } & \multicolumn{2}{c}{ PP Test İstatistiği } \\
\cline { 2 - 5 } & Sabitli Terimli & Sabitli ve Trendli & Sabitli Terimli & Sabitli ve Trendli \\
\hline BİST 100 & $-1,043$ & $-2,660$ & $-0,976$ & $-2,548$ \\
DAX 30 & $-0,713$ & $-3,054$ & $-0,828$ & $-3,109$ \\
FTSE 100 & $-1,447$ & $-2,663$ & $-1,596$ & $-2,791$ \\
FTMIB & $-1,794$ & $-1,965$ & $-1,892$ & $-2,204$ \\
IBEX 35 & $-2,298$ & $-2,374$ & $-2,463$ & $-2,533$ \\
IMOEX & $-1,730$ & $-2,114$ & $-1,723$ & $-2,017$ \\
CAC 40 & $-2,097$ & $-2,220$ & $-2,312$ & $-2,364$ \\
S\&P 500 & $-0,019$ & $-2,097$ & $-0,232$ & $-2,212$ \\
$\Delta$ BİST 100 & $-17,524^{*}$ & $-17,487^{*}$ & $-17,556^{*}$ & $-17,518^{*}$ \\
$\Delta$ DAX 30 & $-14,092^{*}$ & $-14,159^{*}$ & $-14,086^{*}$ & $-14,151^{*}$ \\
$\Delta$ FTSE 100 & $-15,374^{*}$ & $-15,394^{*}$ & $-15,399^{*}$ & $-15,412^{*}$ \\
$\Delta$ FTMIB & $-14,854^{*}$ & $-14,869^{*}$ & $-14,891^{*}$ & $-14,899^{*}$ \\
$\Delta$ IBEX 35 & $-14,514^{*}$ & $-14,491^{*}$ & $-14,506^{*}$ & $-14,482^{*}$ \\
$\Delta$ IMOEX & $-12,366^{*}$ & $-12,379^{*}$ & $-12,367^{*}$ & $-12,383^{*}$ \\
$\Delta$ CAC 40 & $-13,968^{*}$ & $-14,041^{*}$ & $-13,998^{*}$ & $-14,042^{*}$ \\
$\Delta$ S\&P 500 & $-13,821^{*}$ & $-13,922^{*}$ & $-13,886^{*}$ & $-13,931^{*}$ \\
\hline Kritik 1\% & $-3,458$ & $-3,998$ & $-3,458$ & $-3,998$ \\
Değerler 5\% & $-2,873$ & $-3,429$ & $-2,873$ & $-3,429$ \\
\hline 10\% & $-2,573$ & $-3,138$ & $-2,573$ & $-3,138$ \\
\hline
\end{tabular}

Açıklamalar: ${ }^{* * *}$ ve $^{* * *}$ işaretleri $\% 1, \% 5$ ve $\% 10$ düzeylerinde istatistiksel olarak anlamlılığ 1 ifade etmektedir. $\Delta$, birinci fark işlemcisidir.

Tablo 3'te yer alan birim kök test sonuçları, serilerin düzey değerlerinin birim kök içerdiği yani durağan olmadığını; ancak serilerin ilk farkı alındığında durağanlaştığını işaret etmektedir. ADF ve PP birim kök testi sonuçlarına göre tüm değişkenler I(1) olup birinci derecede bütünleşiktir.

Tablo 4'te serilere ait yapısal kırılmalı birim kök test sonuçları verilmiştir. Tabloda yer alan Lee ve Strazicich birim kök testi sonuçlarına göre her iki modelde de hesaplanan test istatistik değerleri kritik değerlerden küçük olduğu için temel hipotez kabul edilir ve seriler durağan değildir. Serilerin birinci farkı alınarak yapılan birim kök testi sonuçları, serilerin durağan olduğu yönündedir. Tablo 4'te rapor edilen Lee ve Strazicich birim 


\section{Y. İltaş - F. Güzel 11/4 (2019) 3051-3062}

kök test sonuçlarına göre modele dahil edilen seriler birinci derecede bütünleşik olup elde edilen bu sonuçlar $\mathrm{ADF}$ ve PP test sonuçlarını desteklemektedir.

Tablo 4: Lee-Strazicich Birim Kök Testi Sonuçları

\begin{tabular}{|c|c|c|c|c|c|}
\hline \multirow{2}{*}{\multicolumn{2}{|c|}{ Değişken }} & \multicolumn{2}{|c|}{ Model A } & \multicolumn{2}{|c|}{ Model C } \\
\hline & & Test İstatistiği & Kırılma Dönemi & Test İstatistiği & Kırılma Dönemi \\
\hline BİST 10 & & $-2,422$ & 2002M01:2008M06 & $-4,610$ & 2002M06:2005:M05 \\
\hline $\mathrm{DA} \times 3$ & & $-2,118$ & 2002M07:2002M10 & $-4,341$ & 2004M07:2008M08 \\
\hline FTSE 1 & & $-2,866$ & 2002M08:2011M09 & $-4,323$ & 2004M07:2008M08 \\
\hline FTMII & & $-2,783$ & 2010M10:2015M01 & $-3,695$ & 2005M11:2011M09 \\
\hline IBEX 3 & & $-2,105$ & 2002M12:2005M07 & $-3,642$ & 2003M01:2008M07 \\
\hline IMOE & & $-2,083$ & 2002M02:2005M10 & $-5,464$ & 2005M09:2008M07 \\
\hline CAC 4 & & $-2,733$ & 2013M12:2014M11 & $-4,209$ & 2004M08:2008M09 \\
\hline S\&P 50 & & $-2,433$ & 2002M08:2011M09 & $-4,327$ & 2003M02:2008M10 \\
\hline$\Delta$ BİST 1 & & $-8,082^{*}$ & & $-9,242^{*}$ & \\
\hline$\triangle \mathrm{DAX}$ & & $-11,905^{*}$ & & $-12,213^{*}$ & \\
\hline$\triangle$ FTSE 1 & & $-8,220^{*}$ & & $-9,038^{*}$ & \\
\hline$\Delta \mathrm{FTMI}$ & & $-8,704^{*}$ & & $-11,379^{*}$ & \\
\hline$\triangle \mathrm{IBEX}$ & & $-7,855^{*}$ & & $-12,406^{*}$ & \\
\hline$\triangle \mathrm{IMOE}$ & & $-11,264^{*}$ & & $-9,061^{*}$ & \\
\hline$\triangle \mathrm{CAC}$ & & $-11,664^{*}$ & & $-12,039^{*}$ & \\
\hline$\triangle S \& P 5$ & & $-7,079^{*}$ & & $-12,241^{*}$ & \\
\hline \multirow{3}{*}{$\begin{array}{c}\text { Kritik } \\
\text { Değerler }\end{array}$} & $1 \%$ & \multicolumn{2}{|c|}{$-4,077$} & \multicolumn{2}{|c|}{$-6,984$} \\
\hline & $5 \%$ & \multicolumn{2}{|c|}{$-3,568$} & \multicolumn{2}{|c|}{$-6,143$} \\
\hline & $10 \%$ & \multicolumn{2}{|c|}{$-3,304$} & \multicolumn{2}{|c|}{$-5,738$} \\
\hline
\end{tabular}

Açıklamalar: $\Delta$, birinci fark işlemcisidir. ${ }^{* * *}$ ve ${ }^{* * *}$ işaretleri $\% 1, \% 5$ ve $\% 10$ düzeylerinde seri birim kök içermektedir şeklinde oluşturulan temel hipotezin reddedildiğini göstermektedir.

\subsection{Eşbütünleşme Testi Sonuçları}

Çalışmada serilerin bütünleşme derecesinin (I(1)) belirlenmesinden sonra, seriler arasında uzun dönemli eşbütünleşme ilişkisinin varllğı iki içsel kırılmaya izin veren Hatemi-J (2008) eşbütünleşme testi ile incelenmiştir. Testin sonuçları Tablo 5'te sunulmuştur.

Tablo 5: Hatemi-J (2008) Eşbütünleşme Test Sonuçları

\begin{tabular}{lccccc}
\hline \multicolumn{1}{c}{ Model } & \multicolumn{3}{c}{ Test İstatistiği } & \multicolumn{2}{c}{ Kırılma Dönemi } \\
\hline $\begin{array}{c}\text { Hatemi-J (C/S) } \\
\text { Rejim Değişimi }\end{array}$ & ADF* & $\mathbf{Z}_{\mathrm{t}}$ & $\mathbf{Z}_{\alpha}$ & TB1 & TB2 \\
\hline BİST 100-DAX 30 & $-7,624^{\mathrm{a}}$ & $-7,905^{\mathrm{a}}$ & $-92,672^{\mathrm{a}}$ & Eki.03 & Haz.06 \\
BİST 100-FTSE 100 & $-7,511^{\mathrm{a}}$ & $-7,499^{\mathrm{a}}$ & $-87,875^{\mathrm{b}}$ & Eki.03 & Kas.05 \\
BİST 100-FTMIB & $-4,963$ & $-4,973$ & $-44,265$ & Mar.04 & Şub.07 \\
BİST 100-IBEX 35 & $-5,633$ & $-5,544$ & $-52,661$ & Eki.03 & May.07 \\
BİST 100-IMOEX & $-5,792^{\mathrm{c}}$ & $-5,717^{\mathrm{c}}$ & $-56,109^{\mathrm{c}}$ & Ara.03 & Eki.06 \\
BİST 100-CAC 40 & $-6,510^{\mathrm{a}}$ & $-6,364^{\mathrm{b}}$ & $-66,373^{\mathrm{c}}$ & Kas.02 & Eki.05 \\
BİST 100-S\&P 500 & $-6,636^{\mathrm{a}}$ & $-6,504^{\mathrm{a}}$ & $-70,394^{\mathrm{c}}$ & Ara.03 & Kas.05 \\
\hline
\end{tabular}

Açıklamalar: $a, b$ ve c sırasıyla $\% 1, \% 5$ ve $\% 10$ anlamlılık düzeylerini göstermektedir. TB1 ve TB2 sırasıyla birinci ve ikinci kırılma zamanını göstermektedir. Kritik değerler Hatemi-J (2008) Tablo 1'den elde edilmiştir.

Tablo 5'teki Hatemi-J (2008) test sonuçlarına bakıldığında $A D F^{*}, Z_{\alpha}$ ve $Z_{t}$ test istatistikleri eşbütünleşme ilişkisini desteklemektedir. Elde edilen bulgular, BİST 100 ile tekli bazda DAX 30, FTSE 100, IMOEX, CAC 40 ve S\&P 500 borsa endeksleri arasında güçlü birer eşbütünleşme ilişkisini işaret etmektedir. BİST 100 ile diğer iki borsa endeksi (IBEX 35 ve FTMIB) arasında ise, uzun dönemli bir ilişkiye rastlanmamıştır. 


\section{Y. İltaş - F. Güzel 11/4 (2019) 3051-3062}

Hatemi-J (2008) eşbütünleşme testi sonuçlarına göre ilgili değişkenlerin uzun dönemde birlikte hareket ettiğinin tespit edilmesinden sonraki adımda uzun dönemli ilişkiyi yansıtan parametrelerin tahminine geçilmiş ve sonuçlar Tablo 6'da sunulmuştur. Tabloda yer alan Rejim I, birinci rejim kayması öncesi katsayıları; Rejim II, birinci rejim kayması sonrası katsayılardaki değişimi; Rejim III, ikinci rejim kayması sonrası katsayılardaki değişimleri göstermektedir.

Tablo 6: HJ Rejim Değişim Tarihleri Dikkate Alınarak Uzun Dönem Katsayıların Tahmini

\begin{tabular}{cccccc}
\hline & BİST100-DAX30 & BİST100-FTSE100 & BİST100-IMOEX & BİST100-CAC40 & BİST100-S\&P500 \\
\hline Rejim I & & & & & \\
$\alpha_{0}$ & $7,574^{*}[12,60]$ & $6,397^{*}[4,99]$ & $8,550^{*}[17,22]$ & $5,680^{*}[3,22]$ & $5,770^{*}[5,55]$ \\
$\beta_{0}$ & $0,209^{*}[2,96]$ & $0,346^{* *}[2,30]$ & $0,146^{*}[1,74]$ & $0,432^{* *}[2,08]$ & $0,511^{*}[3,45]$ \\
\hline Rejim II & & & & & \\
$\alpha_{1}$ & $-14,414^{*}[-8,29]$ & $-22,544^{*}[-4,75]$ & $-3,243^{*}[-3,91]$ & $-16,055^{*}[-4,64]$ & $-32,210^{*}[-4,59]$ \\
$\beta_{1}$ & $1,808^{*}[8,78]$ & $2,747^{*}[4,89]$ & $0,593^{*}[4,45]$ & $2,030^{*}[4,85]$ & $4,659^{*}[4,69]$ \\
\hline Rejim III & & & & \\
$\alpha_{2}$ & $8,407^{*}[5,01]$ & $9,279^{* *}[1,98]$ & $-1,391^{* * *}[-1,69]$ & $15,945^{*}[5,05]$ & $30,474^{*}[4,39]$ \\
$\beta_{2}$ & $-0,963^{*}[-4,85]$ & $-1,038^{* * *}[-1,88]$ & $0,232^{* * *}[1,95]$ & $-1,809^{*}[-4,71]$ & $-4,221^{*}[-4,29]$ \\
\hline
\end{tabular}

Köşeli parantez içindeki değerler $\mathrm{t}$ istatistiklerini göstermektedir. ${ }^{*},{ }^{* *}$ ve $^{* * *}$ sırasıyla $\% 1, \% 5$ ve $\% 10$ anlamlılık düzeyini göstermektedir.

Tablo 6' da rapor edilen uzun dönem katsayıları incelendiğinde, I. rejim döneminde BİST 100 ile DAX 30, FTSE 100, IMOEX, CAC 40, ve S\&P 500 borsa endeksleri arasında uzun dönemde pozitif ve istatistiksel olarak anlamlı ilişkilerin mevcut olduğu görülmektedir. I. rejim döneminde DAX 30, FTSE 100, IMOEX, CAC 40, ve S\&P 500 borsa endeksleri değişkenlerinin katsayıları sırasıyla 0,209, 0,346, 0,146, 0,432 ve 0,511 değerlerini almıştır.

II. rejim dönemi olan birinci kırılma tarihlerinden sonra BİST 100 ile DAX 30, FTSE 100, IMOEX, CAC 40, ve S\&P 500 borsa endeksleri arasında pozitif ve istatistiki olarak anlamlı bir ilişki olduğu görülmektedir. Birinci kırılma tarihinden itibaren DAX 30, FTSE 100, IMOEX, CAC 40, ve S\&P 500 borsa endeksleri değişkenlerinin katsayıları sırasıyla 1,808, 2,747, 0,593, 2,030 ve 4,659'dur. Tablo 6' da yer alan uzun dönem katsayı sonuçlarına göre birinci kırılmadan önce DAX 30 borsa endeksinin katsayısı 0,209 ve istatiksel olarak anlamlı; birinci kırılmadan sonra DAX 30 borsa endeksinin katsayısı 2,017 (=0,209+1,808) değerini almıştır. FTSE 100 borsa endeksinin birinci kırılmadan önceki katsayısı 0,346; birinci kırılmadan sonra FTSE 100 borsa endeksinin katsayısı 3,093 (=0,346+2,747) olmuştur. Birinci kırılmadan önce IMOEX borsa endeksinin katsayısı 0,146; birinci kırılmadan sonra IMOEX borsa endeksinin katsayısı $0,739(=0,146+0,593)$ değerini almıştır. Birinci kırılmadan önce CAC 40 borsa endeksinin katsayısı 0,432; birinci kırılmadan sonra CAC 40 borsa endeksinin katsayısı 2,462 $(=0,432+20,30)$ olmuştur. Son olarak birinci kırılmadan önce S\&P 500 borsa endeksinin katsayısı 0,511 iken birinci kırılmadan sonra S\&P 500 borsa endeksinin katsayısı 5,170 $(=0,511+4,659)$ olmuştur.

İkinci kırılma tarihlerinden sonraki III. rejim dönemine bakıldığında ise BİST 100 borsa endeksi üzerinde IMOEX borsa endeksi hariç diğer dört borsa endeksinin etkisinin negatife döndüğü görülmektedir. III. rejim döneminde DAX 30, FTSE 100, IMOEX, CAC 40, ve S\&P 500 borsa endeksleri sirasiyla -0,963, -1,038, 0,232, 1,809 ve $-4,221$ katsayılarını almıştır. İkinci kırılmadan sonra DAX $30-0,754(=0,209-0,963)$, FTSE $100-0,692$ $(=0,346-1,038)$, IMOEX 0,378 $(=0,146+0,232)$, CAC $40-1,377(=0,432-1,809)$ ve S\&P $500-3,710(=0,511-4,221)$ değerini almıştır.

I., II. ve III. Rejim dönemleri değerlendirildiğinde, Türkiye ile dış ticaretinde önemli yere sahip beş ülke borsası arasında birinci rejim kayması öncesi ve birinci rejim kayması sonrasında ilgili ülke borsa endekslerindeki bir artışın BIST 100'ü pozitif yönde etkilediği görülmektedir. Bu doğrultuda ilgili dönemler için bu ülke borsalarının benzer hareketler sergilediği yorumu yapılabilecektir. İkinci rejim kayması sonrası Moskova Borsası dışındaki diğer dört ülke borsasının BİST 100 üzerindeki pozitif etkisinin negatife döndüğü belirlenmiştir.

Hatemi-J (2008) eşbütünleşme testi sonuçları BİST 100 ile incelenen borsaların beşi (DAX 30, FTSE 100, IMOEX, CAC 40 ve S\&P 500) arasında eşbütünleşme ilişkisi olduğunu işaret etmektedir. Bu kapsamda, incelenen dönemde meydana gelen yapısal değişimlerin borsa endeksleri arasındaki ilişki üzerinde etkili olduğu 


\section{Y. İltaş - F. Güzel 11/4 (2019) 3051-3062}

görülmektedir. Sonuç olarak, modern portföy teorisi çerçevesinde BİST 100 aralarında uzun dönemli bir ilişki tespit edilmeyen FTMIB ve IBEX 35 borsaları için ikame bir yatırım seçeneği olarak kabul edilebilir. Başka bir ifade ile BIST 100'e portföylerinde yer veren yatırımcılar FTMIB ve IBEX 35 endekslerine BIST 100 nedeniyle üstlendikleri riski azaltmak amacıyla yatırım yapabilir ve beraberinde elde edecekleri getiriyi de artırabilme fırsatı bulabilirler.

\section{Sonuç}

Ocak 2000 - Mayıs 2019 dönemi için Türkiye ile dış ticaretinde önemli yere sahip yedi ülkenin borsa endeksleri arasındaki uzun dönemli ilişkilerin araştırıldığı çalışmada değişkenlere ilişkin aylık borsa endeksi kapanış değerlerinden yararlanılmıştır. Bu çalışmada Türkiye (BIST 100) ile ABD (S\&P 500), Almanya (DAX 30), Fransa (CAC 40), İngiltere (FTSE 100), İspanya (IBEX 35), İtalya (FTSE MIB), Rusya (IMOEX) arasındaki ilişki yapısal kırılmalar dikkate alınarak incelenmiştir. Analiz için ilk aşamada, serilerin durağanlıkları Artırılmış DickeyFuller (ADF;1981) ve Phillips-Perron (PP;1988) standart birim kök testlerinin yanı sıra iki içsel kırılmaya izin veren Lee ve Strazicich (2003) birim kök testi ile sınanmıştır. Birim kök sınamasında serilerin ilk farkında durağan oldukları bulgusuna ulaşılmıştır. Birim kök sınamasından sonra ikinci aşamada yapısal değişimleri dikkate alarak değişkenler arasındaki uzun dönemli ilişkiyi incelemek için iki yapısal kırılmaya izin veren Hatemi-J (2008) eşbütünleşme testi kullanılmıştır. Değişkenler arasında eşbütünleşme ilişkisinin varlığı tespit edildikten sonra üçüncü aşamada her bir değişkenin uzun dönemde aldığı katsayı HJ'nin yapısal kırılmaları dikkate alarak uzun dönem katsayılarını tahmininde kullandığı EKK (en küçük kareler) yöntemi ile tahmin edilmiştir.

Elde edilen analiz bulgularına göre; iki yapısal kırılmaya izin veren Hatemi-J (2008) eşbütünleşme testi FTMIB ve IBEX 35 borsa endeksleri hariç DAX 30, FTSE 100, IMOEX, CAC 40 ve S\&P 500 borsa endeksleri ile BİST 100 'ün uzun dönemde birlikte hareket ettiğini ortaya koymaktadır. HJ yapısal kırılmaları dikkate alan uzun dönem katsayı tahmin sonuçları ise I. rejim döneminde BİST 100 ile DAX 30, FTSE 100, IMOEX, CAC 40, ve S\&P 500 borsa endeksleri arasında uzun dönemde pozitif ve istatistiksel olarak anlamlı ilişkilerin mevcut olduğunu ortaya koymaktadır. Yine HJ uzun dönem katsayı tahmin sonuçlarına göre II. rejim dönemi olan birinci kırılma tarihlerinden sonra BİST 100 ile DAX 30, FTSE 100, IMOEX, CAC 40, ve S\&P 500 borsa endeksleri arasında pozitif ve istatistiki olarak anlamlı olan ilişki daha da güçlenmiştir. Analizlerden elde edilen bu bulguya göre birinci rejim kayması öncesi ve birinci rejim kayması sonrasında borsa endekslerindeki bir artışın BİST 100'ü pozitif yönde etkilediğini ve endekslerle benzer hareketleri sergilediğini söylemek mümkündür. İkinci rejim kayması sonrası BISTT 100 ile IMOEX borsa endeksi arasındaki pozitif yönlü ilişki varlığını korurken diğer dört borsa endeksi (DAX 30, FTSE 100, CAC 40, ve S\&P 500) arasındaki ilişki negatif yönlü olmuştur. Birinci kırılma zamanı 2002 yılının sonu ve 2003 yılının başıdır. İkinci kırılma zamanı ise 2005 yılının sonu ve 2006 yılının ortasıdır. Söz konusu bu kırılma tarihlerinden 2002 ve 2003 yılı, krizden sonraki dönemde Türkiye ekonomisinin toparlanma sürecine ve güçlü ekonomiye geçiş programını işaret etmektedir. 2005 ve 2006 yılları ise Türkiye ekonomisi için hızlı büyüme dönemine işaret etmektedir.

Sonuçlar toplu olarak değerlendirildiğinde, BİST 100 endeksinin FTMIB ve IBEX 35 hariç diğer ülke borsaları ile uzun dönemli bir ilişkiye sahip olduğu ve birlikte hareket ettiği olgusuna ulaşılmaktadır. Bu ilişki IMOEX için bütün dönem boyunca pozitif iken, diğer dört borsa (DAX 30, FTSE 100, CAC 40, S\&P 500) için II. kırılma tarihinden itibaren negatife dönmektedir. Kırılma tarihleri finansal krizleri veya kriz öncesindeki/sonrasındaki darboğazları işaret etmekte, ilgili dönemlerde genel dengedeki değişimler ise kuvvetle muhtemeldir. Modern portföy teorisi çerçevesinden bakıldığında, yatırım portföyünde risk azaltma konusunda BİST 100, FTMIB ve IBEX 35 birbirine ikame konumdadır ve BİST 100 endeksine portföyünde yer veren yatırımcının riskini yönetme konusunda FTMIB veya IBEX 35 endeksini tercih edebileceği söylenebilir. Elde edilen bulgular mevcut literatür ile kıyaslandığında, Türkiye ile İspanya ve İtalya borsaları arasında eşbütünleşme ilişkisinin olmadığı ve Türkiye ile Almanya ve Rusya borsaları arasında eşbütünleşme ilişkisi olduğu tespitleri genel sonuçlarla uyum sergilemektedir. Ancak, literatürde Türkiye ile ABD, Fransa ve İngiltere borsaları arasında eşbütünleşme ilişkisinin olmadığına yönelik tespitler ağırlıktadır. Bu açıdan bakıldığında yapılan çalışmanın sonuçları literatürün çoğunluğundan farklı bir olgu ortaya koymaktadır. Dolayısıyla, çalışma mevcut literatürün hâkim görüşler ile İspanya, İtalya, Almanya ve Rusya açısından benzer, ABD, Fransa ve İngiltere açısından farklı sonuçlar ortaya koymaktadır. 


\section{Y. İltaş - F. Güzel 11/4 (2019) 3051-3062}

Çalışmaya konu edilen ülkelerin birbirleri ile olan ilişkisi analizi ve ilgili ülkelerin sayısındaki artış daha geniş kapsamlı ve analitik sonuçların elde edilmesini sağlayacaktır. Bu koşullar ise daha gelişmiş analiz yöntemleri, borsa yönetimlerindeki şeffaflık ve veri senkronizasyonu gibi faktörler neticesinde sağlanabilmektedir. Bununla birlikte, gözlem frekanslarının sıklı̆̆ı ve veri seti döneminin çeşitli varyasyonları ile farklı açılardan yapılacak yorumlar sonuçların güvenilirliğini destekleyecektir. Bu durum ise, farklı çalışmaların konusu olmaya adaydır.

\section{Kaynakça}

Bozoklu, Ş., ve Saydam, İ. (2010). BRIC Ülkeleri ve Türkiye Arasındaki Sermaye Piyasaları Entegrasyonunun Parametrik ve Parametrik Olmayan Eşbütünleşme Testleri ile Analizi. Maliye Dergisi(159), 416-431.

Boztosun, D., ve Çelik, T. (2011). Türkiye Borsasının Avrupa Borsaları ile Eşbütünleşme Analizi. Süleyman Demirel Üniversitesi İktisadi ve İdari Bilimler Fakültesi Dergisi, 16(1), 147-162.

Çıtak, L., ve Gözbaşı, O. (2007). İMKB ile Önde Gelen Gelişmiş ve Gelişmekte Olan Ülke Borsaları Arasındaki Bütünleşmenin Temel Endeks ve Ana Sektör Endeksleri Temelinde Analizi. Dokuz Eylül Üniversitesi İktisadi ve İdari Bilimler Fakültesi Dergisi, 22(2), 249-271.

Dickey, David. A and Fuller, W. A. (1979). Distribution of the Estimators for Autoregressive Time Series with a Unit Root, Journal of the American Statistical Association, 74(366), 427-431.

Dickey, D., ve Fuller, W. (1981). Likelihood Ratio Statistics for Autoregressive Time Series with a Unit Root. Econometrica, 49(4), 1057-1072.

Engle, R. F. anda Granger, C. W. J. (1987). Co-integration and Error Correction: Representation, Estimation, and Testing, Applied Econometrics, 39(3), 107-135. doi:10.2307/1913236

Gregory, A., ve Hansen, B. (1996). Residual-Based Tests for Cointegration in Models with Regime Shifts. Journal of Econometrics, 70(1), 99-126.

Hatemi-J, A. (2008). Tests for cointegration with two unknown regime shifts with an application to financial market integration. Empirical Economics, 35(3), 497-505. doi:10.1007/s00181-007-0175-9

Johansen, S. (1988). Statistical Analysis of Cointegrating Vectors, Journal of Economic Dynamics and Control, $12(2-3), 231-254$.

Johansen, S. and Juselius, K. (1990). Maximum Likelihood Estimation and Inference on Cointegration - With Applications To the Demand for Money, Oxford Bulletin of Economics and Statistics, 52(2), 169-210.

Kaya, T. (2016). 2008 Küresel Ekonomik Kriz Sonrası BIST ve Dünya Borsaları İlişkisi: Kriz İlişkileri Etkiledi mi?. Finans Politik \& Ekonomik Yorumlar, 53(618), 9-30.

Kocabıyık, T., ve Kalaycı, Ş. (2014). Borsalar Arasında Etkileşim: G-8 Ülkeleri ve Türkiye Üzerine Ampirik Bir Araştırma. Finans Politik \& Ekonomik Yorumlar, 51(594), 37-56.

Korkmaz, T., Zaman, S., ve Çevik, E. (2008). Türkiye'nin Avrupa Birliği ve Yüksek Dış Ticaret Hacmine Sahip Ülke Borsaları ile Entegrasyon İlişkisi. ZKü Sosyal Bilimler Dergisi, 4(8), 19-44.

Korkmaz, T., Zaman, S., ve Çevik, E. (2009). İMKB ile Uluslararası Hisse Senedi Piyasaları Arasındaki Entegrasyon İlişkisinin Yapısal Kırılma Testleri İle Analizi. Akdeniz İ.İ.B.F. Dergisi(17), 40-71.

Lee, J. and Strazicich, M. C. (2003). Minimum Lagrange Multiplier Unit Root Test with Two Structural Breaks. The Review of Economics and Statistics, 85(4), 1082-1089.

Mandacı, P., ve Taşkın, D. (2005). AB'ye Uyum Sürecinde İMKB'nin AB Piyasaları ile Karşılaştırılması. Muhasebe ve Finansman Dergisi(26), 127-137.

Onay, C. (2006). A Co-integration Analysis Approach to European Union Integration: The Case of Acceding and Candidate Countries. European Integration Online Papers, 1-11. http://eiop.or.at/eiop/pdf/2006007.pdf adresinden alındı 


$$
\text { Y. İltaş - F. Güzel 11/4 (2019) 3051-3062 }
$$

Özşahin, Ş. (2017). Yükselen Piyasa Ekonomilerinde Menkul Kıymetler Borsalarının Entegrasyonu: Türkiye ve BRICS Ülkeleri Üzerine Çoklu Yapısal Kırılmalı Eş-bütünleşme Analizi. Yönetim ve Ekonomi: Celal Bayar Üniversitesi İktisadi ve İdari Bilimler Fakültesi Dergisi, 24(2), 601-619.

Öztürk, H. (2018). BIST 30 Endeksi ile MSCI Gelişmekte Olan Piyasalar Endeksinin Küresel Kriz Öncesi ve Sonrası Eşbütünleşme Analizi. Business and Economics Research Review Journal, 9(1), 109-121.

Phillips, P.C.B. and P. Perron (1988), “Testing for a Unit Root in Time Series Regression”, Biometrika, 75(2), 335-346.

Polat, M. ve Gemici, E. (2017). Analysis of the Relationship Between BİST And BRICS Stock Markets in Terms of Portfolio Diversification: Cointegration Analysis With ARDL Boundary Test. Journal of Economics, Finance and Accounting, 4(4), 393-403.

Schmidt, P., \& Phillips, P. (1992). LM Tests For a Unit Root in the Presence of Deterministic Trends. Oxford Bulletin of Economics and Statistics, 54(3), 257-287.

Sevüktekin, M., ve Nargeleçekenler, M. (2008). Türkiye ve Amerika'daki Hisse Senedi Piyasaları Arasındaki Dinamik İlişkinin Belirlenmesi. Finans Politik \& Ekonomik Yorumlar, 45(520), 15-22.

TÜİK. (2019). Dış Ticaret İstatistikleri. Ağustos 18, 2019 tarihinde Türkiye İstatistik Kurumu: http://www.tuik.gov.tr/PreTablo.do?alt_id=1046 adresinden alındı

Vuran, B. (2010). IMKB 100 Endeksinin Uluslararası Hisse Senedi Endeksleri ile İlişkisinin Eşbütünleşim Analizi ile Belirlenmesi. İstanbul Üniversitesi İşletme Fakültesi Dergisi, 39(1), 154-168.

Yağlı, İ. (2016). Uluslararası Portföy Çeşitlendirmesi Kapsamında ABD ile BRICS ve Türkiye Hisse Senedi Piyasaları Arasındaki Eşbütünleşme İlişkisinin Analizi, Ekonomi, Politika \& Finans Araştırmaları Dergisi, $1(1-2), 13-22$.

Yılancı, V. (2009). Yapısal Kırılmalar Altında Türkiye İçin İşsizlik Histerisinin Sınanması. Doğuş Üniversitesi Dergisi, 2(10), 324-335. doi:10.31671/dogus.2019.195

Yılancı, V., ve Öztürk, Z. (2010). Türkiye ile en Büyük Beş Ticaret Ortağının Hisse Senedi Piyasaları Arasındaki Entegrasyon İlişksinin Analizi. Erciyes Üniversitesi İktisadi ve İdari Bilimler Fakültesi Dergisi(36), 261-279. 